Phillipson, A. T. \& Mitchell, R. L. (1952). Brit. F. Nutrit., 6, 776.

Schambye, P. \& Phillipson, A. T. (1949). Nature, Lond., 164, 1094.

Shazly, K. \& Synge, R. L. M. (1950). Int. Congr. Physiol. xvirr. Copenhagen, p. 445.

Sherman, J. M. (1937). Bact. Rev. r, 57.

Somogyi, M. (1945). F. biol. Chem. 160, 69.

Stewart, J. (1947). Biochem. F. 4I, xlii.

\title{
Some Observations on the Diet of Jamaican Children, with Particular Reference to Liver Disease
}

\author{
By KATERINA RHODES (Macy Foundation Research Fellow) \\ Department of Pathology, University College Hospital of the West Indies, Mona, \\ St Andrew, Famaica
}

(Received I 8 Fuly 1951)

The object of this communication is to describe the inadequate diet of Jamaican children suffering from liver disease.

\section{EXPERIMENTAL}

Clinical material studied. During the past 15 months, $\mathrm{I}_{5} 5$ cases of liver disease have been investigated in this Department by Hill (195I) and Hill \& Rhodes (195I). Ninety liver biopsies were performed on fifty-eight of the cases by the needle technique and, in addition, ten post-mortem specimens were examined. Though the majority of these patients looked chubby and well nourished, all had an enlarged liver (P1. I) and some had enlargement of the spleen with ascites and, occasionally, oedema of the legs. If ascites was present it refilled rapidly after paracentesis abdominis. None of the patients had malaria or any other acute or chronic infection or infestation with parasites.

The liver sections showed a continuously developing histological picture which we have termed 'serous hepatosis'; this picture, commencing with a serous exudation within the perisinusoidal spaces of Disse, passed on to the laying down of an eosinophilic coagulum which subsequently became fibrosed to give a final appearance of what is usually known as cirrhosis (Hill, 195I). Fatty metamorphosis of the liver as described by Waterlow (1948) was found only in five cases; these however showed, in addition, the fundamental pathological lesions described above. Approximately $30 \%$ of the total number of children, clinically and histologically, had cirrhosis of the liver with fibrosis, hyperplasia and distortion of lobular architecture; these belonged to an older age group and had longer medical histories.

Dietary investigation. The diet of each of the children suffering from liver disease was inquired into during this investigation, but the food intake of ten children was studied in more detail and compared with that of five healthy controls. Their ages varied from 9 months to 8 years, the majority being between 9 months and 3 years. Eight were male. The dietary measurements were made in the children's homes by 


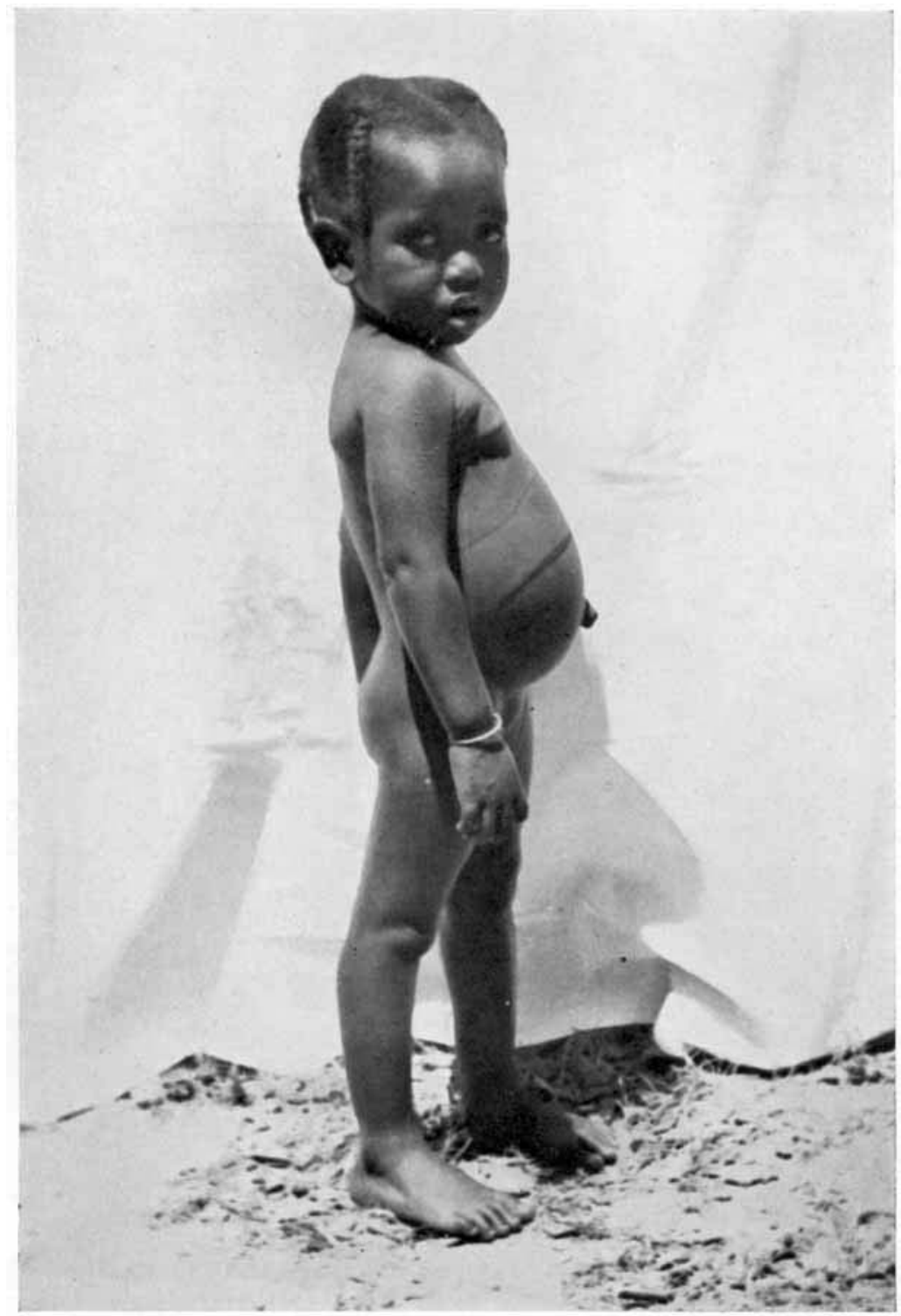

British fournal of Nutrition, Vol. 6, No. 2 
daily visits over a period of 4-7 days. If measurements were conducted for less than 7 days it was because the daily dietary pattern was being repeated without any change whatsoever. All food was weighed in the dry, uncooked state. Co-operation was obtained from the mother or guardian in all cases by making her understand the purpose of the inquiry, thus eliminating errors due to false statements. The same utensils as were used in the preparation of meals, for instance cups and spoons, were used in indicating quantities. The food values were calculated from tables compiled by Platt (1945), Nicholls (1945), Wooster \& Blanck (1949), and the daily averages obtained were compared with the average requirements recommended by the (U.S.A.) National Research Council (1948).

Physical examination. Of the five healthy children, two were seen at the local Child Welfare Clinic and three in the surgical Children's Ward of Kingston Public Hospital. Physical examination revealed no abnormality in these cases. Particular attention was directed towards any enlargement of the liver or spleen or the presence of deficiency disease. The larger group of ten children had obvious liver disease. In all ten the liver was hard and enlarged, two had enlargement of the spleen and three had ascites with oedema. Liver biopsies performed in seven of these cases revealed various stages of the developing hepatic fibrosis described above, i.e. serous exudation followed by an eosinophilic coagulum followed by fibrosis. None of the fifteen cases described were being breast fed at the time of investigation. All came from comparable social strata and were resident in the urban area of Kingston.

\section{RESULTS}

In all figures and tables, nos. I- 5 represent control healthy children and nos. 6-1 5 the sick children with liver disease.

Table I shows age, sex, weight and height and the average daily protein, carbohydrate, fat and calorie intake for each of the fifteen children.

\section{Dietary differences between sick and healthy children}

General. The daily average protein and fat intake of the children with liver disease was invariably much lower than that of the healthy group. For example, child no. 2 of the control group aged 3 years had a daily protein intake of $34.2 \mathrm{~g}$, whereas children, cases nos. I I and $I_{3}$, of the same age had protein intakes of 10 and $19.5 \mathrm{~g}$, respectively. The calculated carbohydrate and calorie intake did not differ in the two groups, except for cases nos. 6 and 8 which were grossly deficient. These children had severe hepatic fibrosis with splenomegaly and did not thrive. It is true that the children with liver disease received fewer calories than those in the control group, but the difference is not sufficiently marked to be significant. The last line in Table I shows the number of different food items taken in one week. The difference between the two groups is marked: the diet taken by the sick children was monotonous, whereas that of the healthy group, taking into account the age of each individual child concerned, was very much more varied.

Protein intake. Fig. I gives a diagrammatic representation of the total protein intake and of the proportion of animal protein in the diet of the two groups. The 
protein standard is calculated as $3.5 \mathrm{~g}$ protein $/ \mathrm{kg}$ body-weight. The animal-protein standard is taken as two-thirds of the total protein ((U.S.A.) National Research Council, I948). Control cases nos. I-5 had a total protein intake ranging from 60 to $78 \%$ of the normal, with an arithmetic mean of $72.5 \%$. These were the healthy children. The children with liver disease (nos. 6-15) had a total protein intake not higher than $52.5 \%$ of the normal, ranging from 13 to $52.5 \%$ with an arithmetic mean of $32.6 \%$.

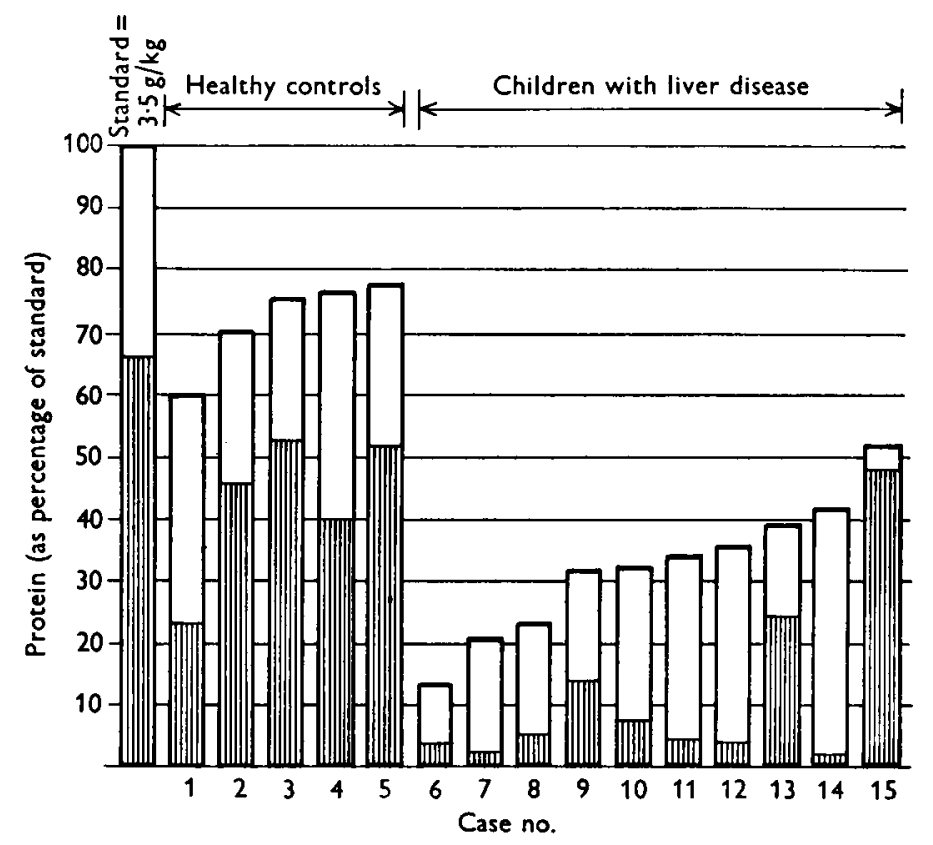

Fig. I. Daily protein intake, and proportion of animal protein, 四, in the diets of the sick and healthy children, expressed as percentages of standards (see top of page).

It is obvious from the diagram that the proportion of animal protein in the diets of the children with liver disease was likewise much smaller than for the healthy children with the exception of cases nos. 14 and 15 which, nevertheless, showed great deficiency compared with the National Research Council standard. It may be suggested that the protein requirements adopted as standard are too high, since even the more adequately fed and healthy children had a deficiency of from 22 to $40 \%$. A standard for the British West Indies has not yet been compiled, but whatever standard requirements are adopted, the difference in the protein intake of the two groups of children will still be significant.

Source of protein. Table 2 presents the different articles of food eaten by the fifteen children. It shows that eight of the ten with liver disease derived their animal protein from a single source only, seven from condensed milk and one from fresh cow's milk. Of the remaining cases (nos. Io and 13) one had only a small quantity of beef in addition to condensed milk, and the other a small amount of beef and egg. Of the healthy children, one, no. 3 , a child 9 months old, obtained all available protein from condensed milk alone. The remaining four children had a combination of sources 

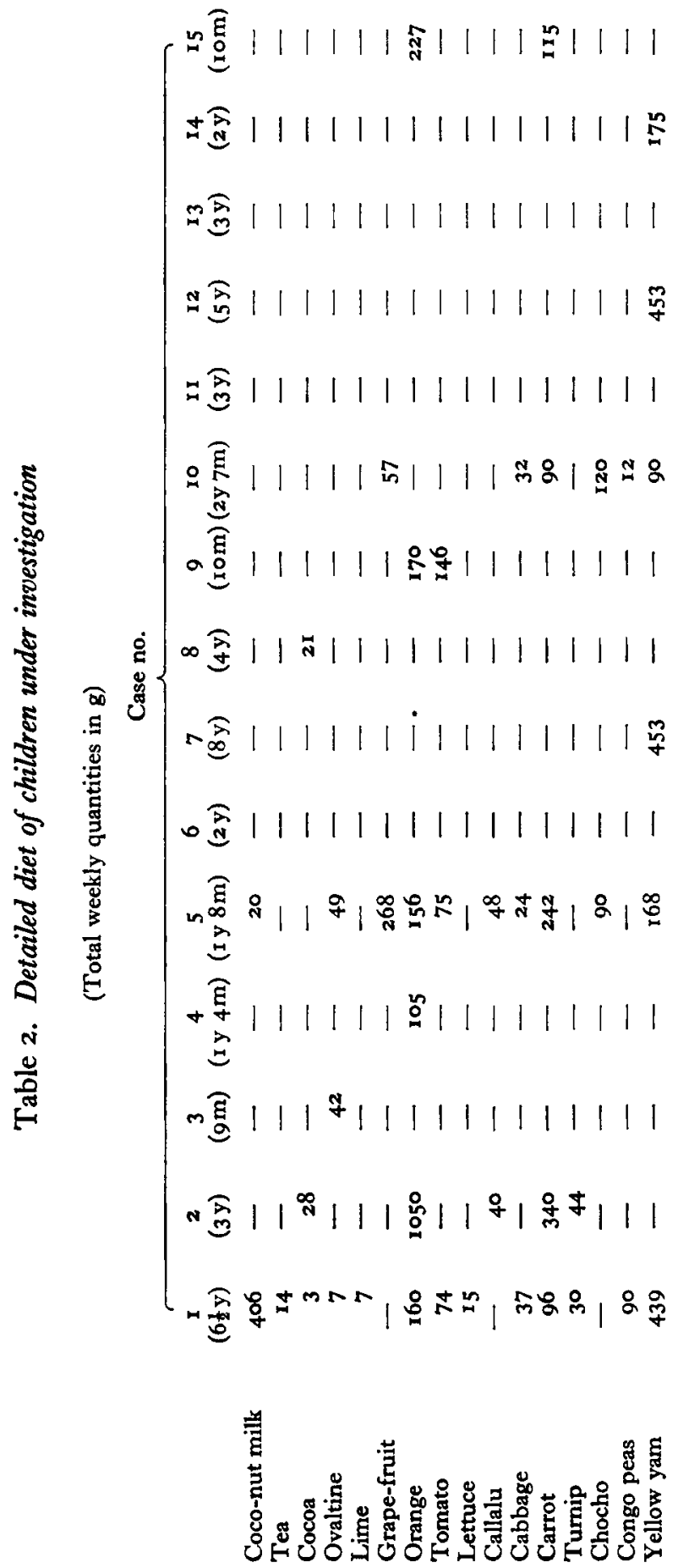
Vol. 6

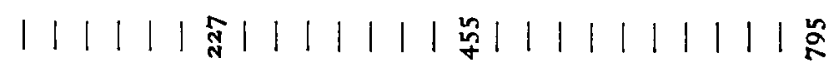
|

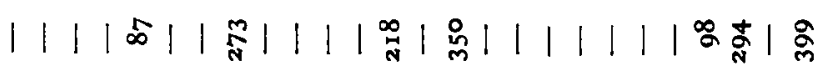

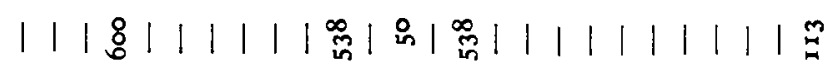

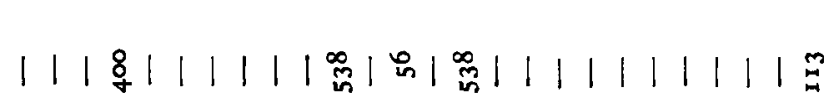

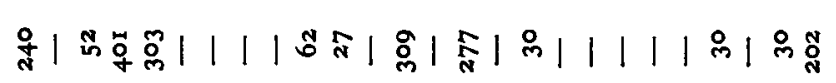

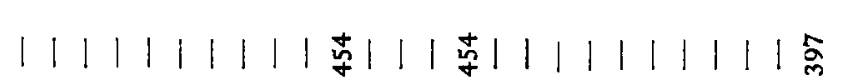

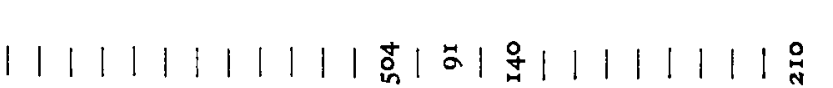
趝

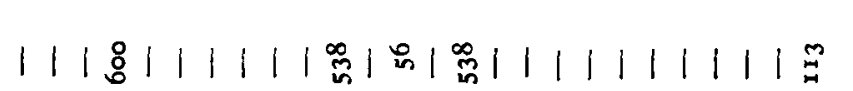

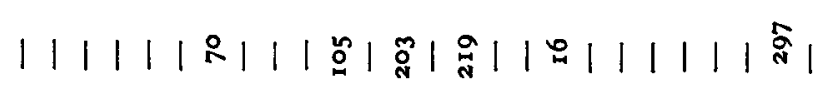

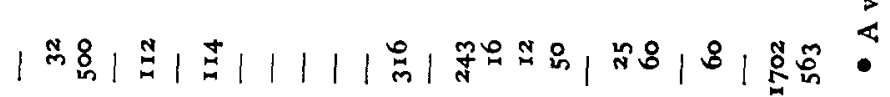

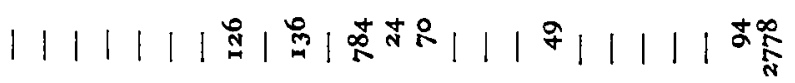

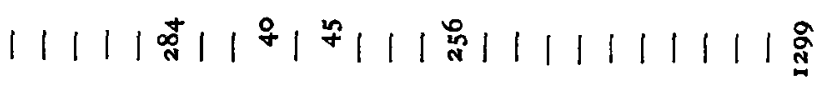

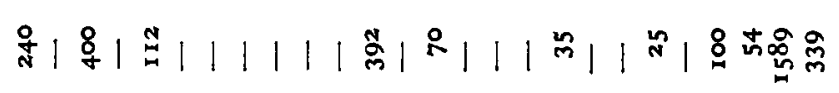

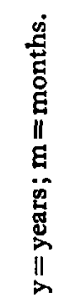
哂

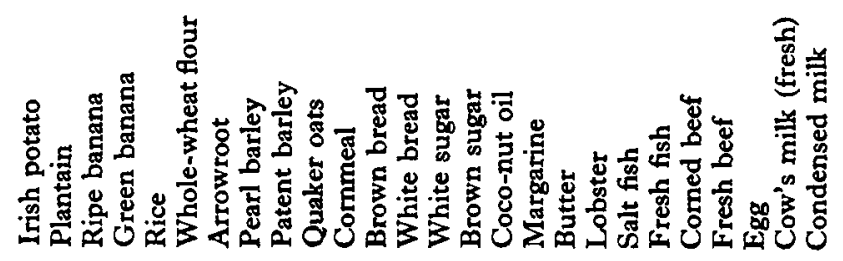


including cow's and condensed milk, eggs, beef and fish. The healthy children averaged $3 \cdot 2$ different sources of animal protein and the sick ones $1 \cdot 3$. There was also a difference in the types of vegetable protein taken by the two groups. In the cases with liver disease, nos. 6-15, the pattern seems to have been one of white bread, maize meal and green banana, whereas control cases, nos. 1-5, had more varied sources with greater protein content, such as brown bread, whole-wheat flour, rice, vegetables and fruit.

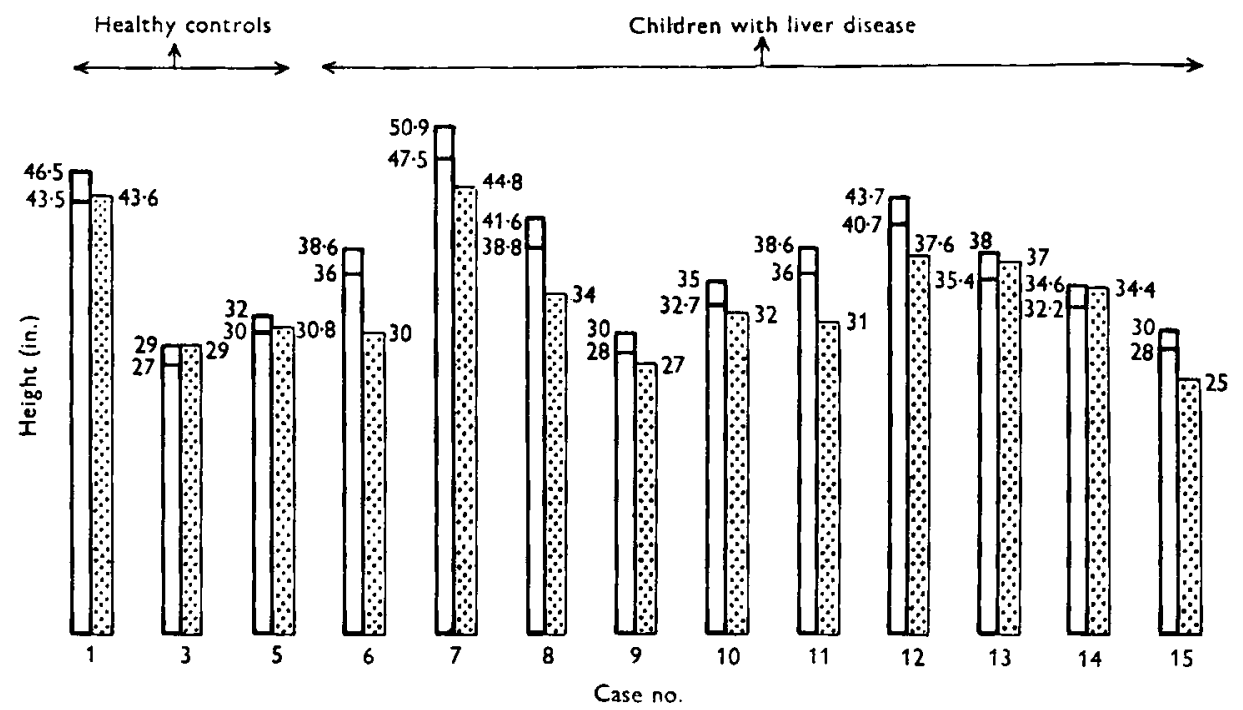

Fig. 2. Comparison of actual with standard heights (Hoit \& McIntosh, 194I) for the sick and healthy children. The white column indicates the standard height with the upper and lower limits of normal variation; the dotted column the actual height of the children.

\section{Heights of the children}

When the height of each child was compared with average heights for similar age groups (Holt \& McIntosh, I94I) it was found that most of the children with liver disease were markedly stunted. Fig. 2 shows the relationship of actual heights to standard heights. Unfortunately, the data for two healthy children were lost. It was noted at the time that all five were not below average height. Our findings concerning the heights of normal children are in agreement with figures obtained in a survey of 2636 girls and 2279 boys in the Kingston area aged from 4 to 15 years, between the years 1935 and 1943 (Cumper, 1950). Children nos. 6-15 were markedly below average, with the exception of nos. 13 and 14 , which were asymptomatic cases of hepatic enlargement found on routine examination, that is to say relatively mild cases.

\section{DISCUSSION}

On the whole, it may be said that the healthy children and most of the children with liver disease discussed here, appeared to be well nourished; however those with liver disease were not so tall as the healthy controls. It is known that the biological value of animal protein is superior to that of protein of vegetable origin, and a mixture of 
proteins has a higher value than single proteins (Nicholls, 1945). The group of children with liver disease had a very low intake both of total protein and of first-class protein of animal origin. However, their monotonous diet supplied them with adequate calories, which were for the greater part derived from sugar and refined cereal foods. The cereal taken was usually a stereotyped one, used day after day and month after month, and it was in the majority of instances yellow degerminated maize meal. The main, and mostly the only, source of first-class protein was in the form of sweetened condensed milk. The Jamaican mother adds sugar to the diluted condensed milk to make it more palatable, thus further increasing the carbohydrate proportion in the milk. This disproportion of carbohydrate to protein may well play a part in the development of liver disease. Furthermore, this monotonous diet may create a deficiency because the protein portion of the cereal used may not be composed of properly balanced essential amino-acids. The child with liver disease, subsisting on a diet that is inadequate, possibly at first compensates by retardation of growth. Later the liver may fail to synthesize certain enzymes of protein origin (Waterlow, 1950). If these enzymes themselves are concerned with protein metabolism, then a vicious circle of dysfunction in protein metabolism may commence. At present it is not known whether the lack of single or multiple amino-acids or the disproportion of protein to carbohydrate intake or perhaps a combination of these factors contributes to the development of liver disease. There may be other aetiological factors at work. It has been found, however, that a diet rich in protein favourably influences the course of the disease. A balanced diet rich in animal protein has met with success in many cases of liver disease. In this series, the time necessary for improvement to become obvious was from 2 to 4 months and sometimes even longer. For this reason, a protein concentrate (Ventriculin, Parke, Davis and Co.) was tried with excellent results and a much more speedy response; improvement, sometimes dramatic, began to take place within $4^{-2 I}$ days. Ventriculin and high-protein foods such as milk and liver had been tried previously in the various liver diseases in children with partial or complete success, reported by Williams (1933) in West Africa, Gillman \& Gillman (1945) in South Africa, Carvalho (1947) in Rio de Janeiro, Altmann (1948) in South Africa, Waterlow (1948) in the British West Indies, Trowell (1949) in West Africa, Thomson (1950) in Malaya and Hill (1950) in Baghdad. Parenteral administration of whole blood or serum by Pieraerts (1949, 1950) in the Belgian Congo, Achar (1950) in India and Van der Sar (1950, personal communication) in Curacao was also of value. These observations are in favour of the conception that one of the underlying causes of liver disease in the tropics is a dietary one.

\section{SUMMARY}

I. The diets of ten Jamaican children with liver disease were compared with those of five apparently healthy Jamaican children.

2. Compared with healthy controls the children with liver disease had a diet deficient in total protein and in animal protein.

3. Their diet contained, in general, only one source of animal protein, in the majority of instances sweetened condensed milk. 
4. The diet lacked variety.

5. It is suggested that one of the underlying causes of liver disease in Jamaican children is dietary.

I am indebted to Professor K. R. Hill for helpful criticism and advice in the preparation of this paper, to Messrs Parke, Davis and Co. (Detroit) for supplying the Ventriculin and to Mrs H. Mills for typing this script.

\section{EXPLANATION OF PLATE}

PI. 1. Jamaican child with liver disease.

\section{REFERENCES}

Achar, S. T. (1950). Brit. med. 7. i, 701.

Altmann, A. (1948). Clin. Proc. 7, 32.

Carvalho, M. (1947). O Hospital, Rio de faneiro, 32, 307.

Cumper, G. E. (1950). Personal communication.

Gillman, T. \& Gillman, J. (1945). Arch. intern. Med. 76, 63.

Hill, K. R. (1950). Personal communication.

Hill, K. R. (195I). Trans. Tenth Conf. Liver Injury. New York: Josiah Macy Jr. Foundation.

Hill, K. R. \& Rhodes, K. (1951). Proc. Int. Congr. clin. Path. F. clin. Path. (Special Suppl.)

Holt, L. E. Jr. \& McIntosh, R. (I94I). Holt's Diseases of Infancy and Childhood, $1 \mathrm{r}$ th ed. New York: D. Appleton Century Co. Inc.

National Research Council (1948). Repr. nat. Res. Coun., Wash., no, 129.

Nicholls, L. (1945). Tropical Nutrition and Dietetics, 2nd ed. London: Baillière, Tindall and Cox.

Pieraerts, G. (1949). Ann. Soc. belge Méd. trop. 29, 329.

Pieraerts, G. (1950). Ann. Soc. belge Méd. trop. 30, 287.

Platt, B. S. (1945). Spec. Rep. Ser. med. Res. Coun., Lond., no. 253.

Thomson, F. A. (1950). Trans. R. Soc. trop. Med. Hyg. 44, 339.

Trowell, H. C. (1949). Trans. R. Soc, trop. Med. Hyg. 42, 417.

Wateriow, J. C. (1948). Spec. Rep. Ser. med. Res. Coun., Lond., no. 263.

Waterlow, J. (1950). Lancet, 258, 908.

Williams, C. D. (1933). Arch. Dis. Childh. 8, 423.

Wooster, H. A. \& Blanck, F. C. (1949). Nutritional Data. Pittsburgh: H. J. Heinz Co. 